\title{
Pengaruh Stres Kerja Terhadap Kepuasan Kerja Perawat Di Ruang Rawat Inap Rumah Sakit Krakatau Medika Cilegon
}

\author{
Oleh: \\ Lisa Widiharti \\ Politeknik Negeri Bandung
}

\begin{abstract}
:
Job satisfaction can improve durability individuals to stress and impacts of stress and on the other hand, a stress that perceived by individual can be a source of discontent. This research aims to know the influence of work stress of job job satisfaction of nurses's in internist room of Krakatau Medika Hospital Cilegon. Research method the used is descriptive method, whith technique data collecting of scale enquette five category of likert, to 215 nurses which have experienced of nurses's room of Krakatau Medika Hospital Cilegon. While to test the research hypothesis, the authoruse a simple regresion analysis method with help of software SPSS 20. The results showed job stress in nurses in the inpatient unit Krakatau Medika Hospital in moderate category is 2.88 and the job satisfaction of nurses are in high category. Work stress experienced by nurses at Krakatau Medika Hospital has a positive effect on job satisfaction, so the impact of positive stress is used as a motivational well as improved performance. The results of correlation calculations, the independent variables on satisfaction postitif relationships with low clasification, the amount of work stress on job satisfaction, which is $12.4 \%$ and the remaining $87.6 \%$ influenced by other factors not described in this study, other factors such as remuneration, staffing, work environment, leadership style, and so on.
\end{abstract}

\section{Keywords: Job Stress, Job Satisfaction.}

\section{Pendahuluan}

Perawat merupakan komponen penting sebagai sumber daya manusia di dalam rumah sakit, karena perawat merupakan aset utama rumah sakit yang memberikan kontribusi dalam pencapaian tujuan perusahaan. Perawat adalah seseorang yang telah lulus pendidikan perawat baik di dalam maupun di luar negeri dengan peraturan perundang-undangan (UU No 38 Tahun 2014, Pasal 1).Asumsi masyarakat tentang perawat yaitu orang yang berjasa, cekatan, perhatian kepada orang lain, bekerja dengan hati, dapat dipercaya dan bersahabat, profesi sebagai perawat juga mempunyai tanggung jawab besar dalam memberikan pelayanan yang professional. Hal ini merupakan stressor yang kuat pada perawat di lingkungan kerjanya.

Pengertian stres menurut Rivai (2014: 323), yaitu suatu kondisi ketegangan yang mempengaruhi emosi, proses berpikir dan kondisi seseorang dimana ia terpaksa memberikan tanggapan melebihi kemampuan penyesuian dirinya terhadap suatu tuntutan eksternal (lingkungan).

Stres kerja karyawan merupakan bagian dari penyebab tingkat kepuasan kerja karyawan. Kepuasan kerja adalah sikap atau perasaan puas atau tidak puas karyawan terhadap hasil penilaian dari pekerjaan yang telah dilakukan. Hal ini sejalan dengan pendapat Rivai (2014: 246) memandang kepuasan kerja sebagai penilaian dari pekerja tentang seberapa jauh pekerjaan secara keseluruhan memuaskan kebutuhan.

PT Krakatau Medika adalah rumah sakit umum yang berada di kota Cilegon, tercatat ada sembilan perusahan yang bergerak di bidang industri selaku pemegang saham dari PT Krakatau. Selain itu masyarakat yang tinggal di daerah Serang dan Cilegon menjadi target pasar dari Rumah Sakit Krakatau Medika. Rumah Sakit Krakatau Medika merupakan rumah sakit umum dengan kelas B, yang berstandar international, oleh karena itu Rumah Sakit Krakatau Medika menjadi pusat rujukan di daerah Cilegon dan Serang.

Menurut Locke dalam Wahjono (2010: 151) banyak penelitian telah dilakukan untuk menemukan hubungan antara kepuasan kerja, stres kerja, dan prestasi kerja. Kepuasan kerja baisanya didasarkan pada prespsi karyawan terhadap karakteristik pekerjaan dalam suatu waktu, ganjaran yang memuaskan, hubungan baik dengan rekan kerja.

Menurut Terry Beehr dalam Suhendi (2010: 215), menyimpulkan tiga gejala stres pada individu, yaitu gejala psikologis, gejala fisiologis, dan gejala prilaku. Berdasarkan hasil wawancara terstruktur kepada 16 perawat yang berada di ruang rawat inap unit dahlia dan unit anggrek 
menunjukan bahwa, 44,7\% perawat mengalami stres kerja dengan gejala fisiologis meliputi, sebagian besar perawat merasa sakit otot terutama leher, bahu, dan pinggan walaupun tidak ada riwayat trauma, dan responden sering merasa lelah dalam melakukan pekerjaan. Untuk gejala stres apkes psikologis, menunjukan sebanyak 57\% responden merasa malas bekerja, merasa cendrung tegang apabila melakukan kesalahan dalam bekerja, dan responden merasa kemampuan untuk mengingat sesuatu menjadi menurun. Sedangkan 58\% responden merasakan gejala stres berdasarkan aspek prilaku, yang ditunjukan dengan jawaban dominan responden terhadap prilaku makan yang tidak normal, perawat kadang melakukan izin kerja, dan perawat merasa kualitas hubungan interpersonal dengan keluarga/ teman menjadi menurun.

Salah satu indikasi yang menyebabkan terjadi stres kerja pada perawat yaitu adanya beban kerja tinggi karena ada kekurangan kebutuhan tenaga keperawatan di ruang rawat inap sehingga menjadikan salah satu penyebab stres kerja. Bagi perusahaan, konsekuensi stres yang timbulnya bersifat tidak langsung adalah meninggkatnya absensi, menurunya tingkat produktivitas, secara psikologis dapat menurunkan komitmen organissai, memicu perasaan terlaliensi, hingga turnover (Rivai,2014: 323).

Tingkat turnover karyawan, mencerminkan kinerja karyawan pada Rumah Sakit Krakatau Medika. Berikut ini ditampilkan gambar garafik menganai data tingakat turnover perawat di Rumah Saikt Krakatau Medika pada priode 2012-2015, yaitu sebagai berikut

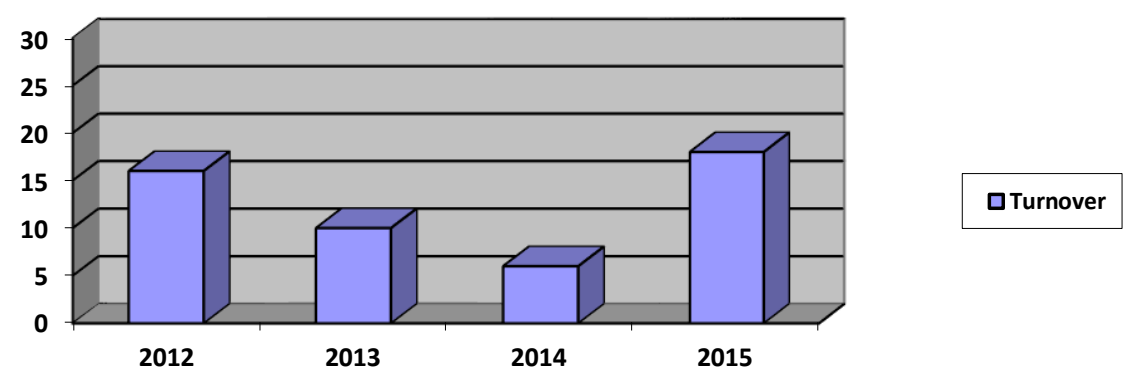

Gambar 1 Jumlah Turnover Perawat Rumah Sakit Krakatu Medika pada Periode 2012-2015 Sumber: Data Internal Rumah Sakit Krakatau Medika (2016)

Berdasarkan grafik diatas menunjukan bahwa tingkat turnover perawat di rumah sakit Krakatau Medika mengalami peningkatan. Hal ini terlihat dari jumlah perawat yang memiliki tingkat turnover yang tinggi pada tahun 2012 yaitu sebanyak 16 karyawan yang keluar, pada tahun 2015 tingkat turnover karyawan mengalami peningkatan kembali, hal ini terlihat pada tahun 2015 sebanyak 18 orang perawat rumah sakit Krakatau medika keluar. Dari informasi yang diberikan oleh kepala perawat berdasarkan hasil wawancara yang diperoleh informasi penyebab meningakatnya turnover perawat yaitu hampir semua disebabkan karena mengundurkan diri secara sukarela, dan sebagian lagi dikarenakan masa kontrak kerja habis.

Penelitian yang dilakukan oleh Mansoor, et al. (2011) menjelaskan bahwa stres kerja berpengaruh negatif dengan kepuasan kerja. Sedangkan penelitian yang dilakukan oleh I Gede (2014), menyebutkan bahwa stres kerja berpengaruh negative terhadap kepuasan kerja, hal ini menunjukan bahwa semakin tinggi stres kerja maka kepuasan kerja karyawan akan semakin menurun begitu pula sebaliknya.

Pengukuran kepuasan kerja tenaga perawat, tidak hanya penting untuk mengetahui kinerja rumah sakit, terutama bidang ketenagakerjanya tetapi juga untuk menentukan strategi manajemen dimasa mendatang. Berdasarkan fenomena yang terjadi dilapangan, peneliti mengidentifikasikan bahwa salah satu faktor yang mempengaruhi kepuasan kerja perawat pada bagian rawat inap di Rumah Sakit Kraktau Medika adalah faktor stres kerja. Stres dalam tingkat yang cukup akan memotivasi karyawan dalam menyelesaiakan tunututan kerja yang dibebankan kepada karyawan. Dengan kondisi karyawan yang jauh dari stres yang belebihan, hal ini akan menimbulkan perasaan suka terhadap pekerjaan dan juga meningkatkan kepuasan kerja karyawan.

Latar belakang dan research gap yang telah dipaparkan di atas dapat dijadikan suatu permasalahan penelitian mengenai pengaruh stres kerja terhaap kepuasan kerja. Oleh karena itu, 
penelitian ini mengambil judul "Pengaruh Stres Kerja Terhadap Kepuasan Kerja Perawat di Ruang Rawat Inap Rumah Sakit Krakatau Medika Cilegon.

\section{Perumusan Masalah}

Berdasarkan latar belakang yang telah diuraikan sebelumnya, maka permasalahan yang ingin dianalisis adalah sebagai berikut:

1. Bagaimana gambaran stres kerja perawat di bagian rawat inap Rumah Sakit Krakatau Medika Cilegon.

2. Bagaimana gambaran kepuasan kerja perawat bagian rawat inap di Rumah Sakit Krakatau Medika Cilegon.

3. Bagaiamana Pengaruh stres kerja terhadap kepuasan kerja perawat bagian rawat inap di Rumah Sakit Krakatau Medika Cilegon.

\section{Tujuan Penelitian}

Tujuan yang hendak dicapai dari penelitian ini adalah sebagai berikut:

1. Mengetahui gambaran stres kerja yang dirasakan perawat di runag rawat inap Rumah Sakit Krakatau Medika.

2. Mengetahui gambaran kepuasan kerja perawat diruang rawat inap Rumah Sakit Krakatau Medika.

3. Untuk mengetahui pengaruh stres kerja terhadap kepuasan kerja perawat di Rumah Sakit Krakatau Medika.

\section{Hipotesis Penelitian}

Berdasarkan latar belakang masalah, tujuan penelitian dan tinjauan pustaka maka hipotesis yang dibuat sebagai berikut:

Ho: Tidak terdapat pengaruh positif \& signifikan anatara stres kerja terhadap kepuasan kerja karyawan.

Ha: Terdapat pengaruh positif dan signifikan antara stres kerja terhadap kepuasan kerja karyawan.

\section{Tinjauan Pustaka \\ Stres Kerja}

Moorhed \&Griffin (2013: 175), medefinisikan stres (stress) sebagai respon adaftif seseorang terhadap rangsangan yang menempatkan tuntutan psikologis atau fisik secara berlebihan kepadanya.

Definisi stres kerja menurut Seyle (1992) dalam Suhendi \& Anggara (2010: 211) dinyatakan sebagai berikut:

"work stress is an individual's response to work related environmental stressors. Stress as the reaction of organism, which can be physicological, psychhologyal, or behaviorar reaction".

Rivai (2014: 308), memahami. stres yaitu sebagai suatu kondisi ketegangan yang mempengaruhi emosi proses berpikir dan kondisi seseorang dimana ia terpaksa memberikan tanggapan melebihi kemampuan penyesuaian dirinya terhadap suatu tuntutan eksternal (lingkungan).

Quick dan Quick (1984) dalam Rivai (2014: 308) menulis katagori jenis stres kerja menjadi dua, yaitu: Eutress, yaitu hasil dari respons terhadap stres yang bersifat sehat, posistif, dan konstruktif (bersifat membangun). Distress, yaitu hasil dari respons terhadap stres yang bersifat tidak sehat, negatif, dan destruktif (bersifat rusak).

Akibat adanya Stres, baik fisik maupun mental sangat mempengaruhi terhadap dinamika prilaku seseorang tergantung bagaimana ia menghadapi atau merespons kondisi ang menimbulkan stres itu sendiri. Menurut Rivai (2014: 316), menjelaskan bahwa pengaruh stres kerja ada yang menguntungkan maupun merugikan bagi perusahaan. Menurut Arnold (1986) dalam Suhendi \&Anggara (2010: 214), menyebutkan bahwa ada empat konsekuensi yang dapat terjadi akibat stres kerja yang dialami oleh individu, yaitu terganggunya kesehatan fisik, kesehatan psikologis, performance, serta mempengaruhi individu dalam mengambil keputusan.

Indikator stres kerja menurut Leung et al (2007), yaitu 1) Prilaku pribadi, yaitu keadaan atau aktifitas dari karyawan itu sendiri di dalam organisasi. 2) Dukungan social, yaitu dukungan dari dalam organisasi. 3) Konflik peran, yaitu kondisi dimana karyawan memikul tugas atau jabatan dan menanggung semua kosekuensi yang berhubungan dengan pekerjaan dalam perusahaan. 4) Lingkungan buruk, yaitu keadaan disekitar organisasi terutama dalam ruang kerja. 5) Beban kerja, 
yaitu keadaan pekerjaan yang dibebankan kepada karyawan atau jenis pekerjaan yang harus diselasaikan tepat waktu, 6) Situasi Rumah dan kondisi pekerjaan di rumah tangga adengan keadaan yang ada di perusahaan. Sedangkan tolak ukur stres kerja menurut Robbins dan Timothy (2013: 598), yaitu sebagai berikut: Ambigutas peran, Konflik Peran, Peran Berlebih, Tuntutan antar Pribadi, Tuntutan antar Pribadi

Berdasarkan penjelasan dimensi-dimensi kerja diatas, maka dalam penelitian peneliti menggunakan dimensi stres kerja sebagai berikut: Ambigutas peran, Konflik Peran, Peran Berlebih, Tuntutan antar Pribadi, Tuntutan antar Pribadi, dan Situasi Rumah dan kondisi pekerjaan.

\section{Kepuasan Kerja}

Menurut Kreitner dan Kinichi (2014: 169) menjelaskan bahwa kepuasan kerja (job satisfaction) adalah sebuah tanggapan afektif atau emosional terhadap berbagai segi pekerjaan seseorang. Menurut Mangkunegara (2013: 117) perasaan yang berhubungan dengan pekerjaan melibatkan aspek-aspspek seperti upah atau gaji yang diterima, kesempatan pengembangan karir, hubungan dengan pegawai lainya.

Penyebab kepuasan kerja, ada juga faktor penentu kepuasan kerja menurut Afandi (2016: 60). Diantaranya adalah sebagai berikut: Pekerja itu sendiri (work itself), Hubungan dengan atasan (supervision), Teman sekerja (coworkers), Promosi (promotion), Gaji atau upah (pay).

Menurut Robbins dan Timothy, (2014: 112), dampak dari Ketidakpuasan karyawan dapat dinyatakan dalam sejumlah cara, antara lain: Keluar (exit), yaitu perilaku yang ditujukan untuk meninggalkan organisasi, Aspirasi (voice), yaitu secara aktif dan konstruktif berusaha memperbaiki kondisi, Kesetiaan (loyalty), yaitu secara pasif tetapi optimistis menunggu membaiknya kondisi, Pengabaian (neglect), yaitu secara pasif membiarkan kondisi menjadi lebih buruk.

Indikator kepuasan kerja menurut Luthans (2006) terbagi atas skala penilaian yaitu, sebgai berikut: 1) Pekerjaan itu sendiri yang terbagi atas pekerjaan sesuai dengan keahlian, tugas yang penting dan peluang dalam mengambil keputusan. 2) Imbalan yang terbagi atas gaji sesuai standar perusahaan, gaji sesuai tuntutan pekerjaan dan bonus sesuai dengan kemampuan. 3) Kesempatan promosi yang terbagi atas kesempatan promosi secara adil dan kesempatan promosi sesuai prestasi karyawan. 4) Pengawasan yang terbagi atas memperlakukan bawahan dengan cara yang baik dan adanya perhatian dari atasan dalam melakukan pekerjaan. 5) Rekan kerja yaitu kesesuaian terhadap rekan kerja mengenai hal - hal yang berkaitan dengan pekerjaan

Tsai dan Huang (2008), mengemukakan ada lima indikator kepuasan kerja meliputi yang pertama pengawasan yaitu keberadaan seseorang yang senantiasa memberikan perintah atau petunjuk dalam pelaksanaan kerja. Kedua rekan kerja yaitu teman-teman kepada siapa seseorang senantiasa berinteraksi, dalam pelaksanaan pekerjaan seseorang dapat merasakan rekan kerjanya sangat menyenangkan atau tidak menyenangkan. Ketiga upah yaitu jumlah bayaran yang diterima seseorang sebagai akibat dari pelaksanaan kerja, apakah sesuai dengan kebutuhan yang dirasakan adil. Keempat promosi yaitu kemungkinan seseorang dapat berkembang melalui kenaikan jabatan. Kelima pekerjaan itu sendiri yaitu isi pekerjaan yang dilakukan seseorang apakah memiliki elemen yang memuaskan.

Stres yang berlebihan dapat mengakibatkan turunnya kepuasan kerja karyawan. Menurut Umar (2011:45), gejala stres kerja di tempat kerja dapat dilihat dari kepuasan kerja yang rendah. Begitu pula yang dapat kita lihat dari model yang dikemukakan oleh Moorhed dan Griffin (2013) bahwa menurunya kepuasan kerja merupakan dampak organisasional dari stres kerja yang dialami oleh karyawan .

Kepausan kerja kerap diakitakan sebagai pengaruh psikologi yang dirasakan jika terjadi stres kerja. Ini berarti bahwa jika stres kerja meningkat, maka kepuasan kerja akan menurun. Sedangkan menurut Robbins (2008; 337 ), mengemukakan bahwa:

Dari sudut pandang organisasi, manajemen mungkin tidak peduli ketika karyawan mengalami tingkat stres rendah hingga menengah. Alasanya, sebagaiman kita singgung sebelumnya, adalah bahwa kedua stres ini mungkin bermanfaat dan membuahkan kinerja karyawan yang lebih tingggi. Akan tetapi, tingkat stres yang tinggi, atau meski rendah tetapi berlangsung terus-menerus dalam priode lama, dapat menurunkan kinerja karyawan dan, dengan demikian, membutuhkan tindakan dari pihak manajemen. 
Berdasarkan penjelasan diatas, untuk mengetahui tingkat stres kerja dan pengaruhnya terhadap kepuasan kerja yang dirasakan oleh perawat, maka peneliti menggunakan dimensi stres kerja yang diadaptasi dari Robbins dan Timothy (2013), dan menurut Leung et al (2007), sedangkan untuk kepuasan kerja penilitian menggunakan dimensi yang diadopsi dari Tsai dan Huang (2008). Berikut gambar kerangka pemikiran dari penelitian mengenai Stres Kerja dan Kepuasan Kerja:

\begin{tabular}{|l|l|}
\hline Stres Kerja $(\mathbf{X})$ & Kepuasan Kerja (Y) \\
\hline Ambiguitas peran & \\
Konflik Peran & Pengawasan \\
Peran berlebih & Rekan Kerja \\
Tuntutan antar pribadi & Upah \\
Stuktur organisasi & Promosi \\
Situasi rumah dan pekerjaan & Pekerjaan itu sendiri \\
\hline
\end{tabular}

Sumber: Data Olahan Penulis, (2016).

\section{Gambar 2 Kerangka Penelitian}

\section{Metode Penelitian}

Metode yang digunakan dalam penelitian ini adalah metode penelitian kauntitatif. Berdasarkan tingkat eksplanasinya (penjalasan) maka, jenis penelitian yang digunakan adalah metode deskriptif dan metode veritifikatif. Dengan metode deskriptif dapat diperoleh mengenai stres kerja dan kepuasan kerja perawat Rumah Sakit Krakatau Medika. Sedangkan metode penelitian verifikatif menguji kebenaran suatu hipotesis dengan cara pengumpulan data dari lapangan, dimana dalam metode penelitian verifikatif ini bertujuan untuk mengetahui pengaruh stres kerja terhadap kepuasan kerja perawat di Rumah sakit Krakatau Medika kota Cilegon. Anggota populasi dalam penelitian ini berjumlah 215 perawat di bagian rawat inap Rumah sakit Krakatau Medika Cilegon. Sedangkan metode pengambilan sampel yang digunakan adalah metode probability sampling. Data penelitian terdiri dari data primer dan data sekunder.

Dalam penelitian ini kuisoner yang digunakan didesain dengan menggunakan skala likert dengan bobot nilai 1-5. Uji validitas dan reliabilitas telah dilakukan dengan memberi hasil bahwa uji validitas dilakukan pada setiap butir soal atau nilai $\mathrm{r}$ hitung (dapat dilihat pada kolom corrected itemtotal correlations) hasilnya dibandingkan dengan $\mathrm{r}$ tabel di mana degree of freesom $(\mathrm{df})=\mathrm{n}-2$, dalam hal ini $\mathrm{n}$ adalah jumlah sampel dan $\mathrm{k}$ adalah item dengan tingkat kesalahan 5\%. Jika $\mathrm{r}$ tabel $<\mathrm{r}$ hitung, maka butir soal tersebut valid. Maka butir soal tersebut valid (Noor, 2014: 19). Selain itu, kedua variabel adalah reliable, karena menurut Arikunto (2010: 239) nilai minimum dimensi pembentuk variabel yang dapat diterima adalah $\geq 0,60$.

Metode analisis data yang digunakan untuk menganalisis data yang diperoleh antara lain metode analisis statistik deskriptif, uji asumsi klasik, analisis korelasi sederhana, analisis regresi linier sederhana, dan uji hipotesis.

\section{Hasil Penelitian}

Karakteristik responden yang diamati dalam penelitian ini meliputi jenis kelamin, umur, tingkat pendidikan, status dan masa kerja dari 140 perawat yang bekerja di ruang rawat inap Rumah Sakit Krakatau Medika. Analisis identitas responden berdasarkan usia responden menunjukan bahwa jumlah perawat yang berusia 31 sampai 35 tahun yaitu sebanyak 49 orang atau $35 \%$, hal ini menunjukan bahwa perawat yang berusai 31 sampai 35 tahun lebih dominan dalam penelitian ini. Dibandingkan dengan perawat yang berusia antara 26 sampai 30 tahun yaitu 32,86\% atau sebanyak 46 orang. Untuk perawat yang berusia 21 sampai 25 tahun yaitu sebanyak 12 orang atau $8,57 \%$, dan perawat yang berusia 36 sampai 40 tahun yaitu sebanyak 27 orang atau 19,29\%, sedangkan responden 
yang menjawab berdasarkan usia diatas dari 40 tahun berjumlah 6 orang atau 4,29\%, hal terebut menunjukan responden yang menjawab berdasarkan umur tersebut termasuk dalam katagori paling sedikit dalam menjawab kuisoner. Identitas responden berdasarkan lama kerja didominasi oleh perawat yang masa kerjanya antara 1 sampai 5 tahun, yaitu sebanyak 45 perawat, kemudian disusul dengan jumlah respon seanyak 28 orang atau 20\%, dimiliki oleh perawat dengan masa kerjanya 6 sampai 10 tahun dan lebih dari 21 tahun. Responden yang memiliki masa kerja kursng dari 1 tahun yaitu sebanyak 24 orang atau $17,14 \%$, sedangkan perawat yang memilik masa kerjanya antara 11 tahun 20 tahun, yaitu sebesar 15 orang atau 10,71 \%. Identitas responden berdasarkan status, didominasi oleh perawat yang telah bersatatus menikah, yaitu sebanyak 118 orang atau 84,29\%. Sedangkan untuk perawat yang belum menikah atau masih lajang yaitu sebanyak 22 orang atau $15,71 \%$. Identitas responden berdasarkan pendidikan terakhir resonden. Perawat yang memiliki pendidikan terakhir D3 Keperawatan, sebanyak 136 orang atau 97,86\% sedengakan perawat yang berpendidkan S1 yaitu sebanyak 21,14\%.

Tabel 1 Statistik Deskriptif Variabel Stres Kerja

\begin{tabular}{|l|r|r|r|r|r|}
\hline & $\mathrm{N}$ & Minimum & Maximum & \multicolumn{1}{c|}{ Mean } & $\begin{array}{c}\text { Std. } \\
\text { Deviation }\end{array}$ \\
\hline Dimensi Role Ambiguity & 140 & 1.50 & 4.00 & 2.8286 & .57768 \\
\hline Dimensi Role Conflict & 140 & 1.33 & 4.00 & 2.6571 & .55539 \\
\hline Dimensi Role Overload & 140 & 1.50 & 3.75 & 2.8321 & .50040 \\
\hline Dimensi Interpersonal & 140 & 1.40 & 4.00 & 2.6886 & .53228 \\
\hline Dimensi Struktur organisasi & 140 & 1.40 & 3.60 & 2.4771 & .49317 \\
\hline $\begin{array}{l}\text { Dimensi Situasi Rumah dan } \\
\text { Pekerjaan }\end{array}$ & 140 & 2.50 & 5.00 & 3.8500 & .51138 \\
\hline STRES KERJA & 140 & 2.06 & 3.59 & 2.8889 & .33738 \\
\hline Valid N (listwise) & 140 & & & & \\
\hline
\end{tabular}

Sumber : Hasil olah SPSS (2016)

Berdasarkan tabel diatas, nilai mean variabel stres kerja menunjukan angka sebesar 2,88 yang artinya bahwa rata-rata dari jawaban responden sebesar 2,88. Merujuk pada tabel 3.8 mengenai interprestasi nilai hasil analisi deskriptif yang terdapat pada Bab 3, mean dengan interval 2,61 sampai 3,40 berada pada tingkat sedang. Standar deviasi variabel stres kerja menunjukan angka 0,337 atau sama dengan $11,67 \%$ (standar deviasi/mean x 100), artinya standar deviasi variabel stres kerja tidak lebih dari 20\% nilai mean-nya dan menunjukan bahwa variasi jawaban kecil atau sebagian besar responden menjawab peryataan dalam variabel ini dengan jawaban relatif sama. $1 . \quad$ Hasil penelitian menujukan bahwa stres kerja pada dimensi situasi rumah dan pekerjaan, dengan nilai tertinggi yaitu 3,85 yang termasuk pada katagori sedang. Namun pada dimensi struktur organisasi memiliki nilai terendah yaitu 2,47 yang menunjukan katagori rendah.

Identitas responden berasarkan status pernikahan, menunjukan bahwa sebagian besar responden yang sudah menikah yaitu sebanyak 118 orang dari 140 orang atau 84,29\%. Hal tersebut dapat menjadi indikasi tingkat stres sedang yang di alami perawat Rumah Sakit Krakatau Medika Cilegon. Hal ini disebabkan seseorang yang sudah menikah memiliki peran dan tanggung jawab yang lebih dalam hal perannya sebgai suami/istri dibandingkan dengan yang belum menikah. Selain itu, waktu kerja kerja perawat adalah kerja shift sehingga kemungkinan berkuranganya waktu kebersamaan dalam keluarga yang dapat meningkatkan risiko untuk tekena stres.

Menurut Ratna (2010) menenumkan bahwa wanita mengalami stres tinggi dibandingkan dengan pria. Ada beberapa alasan mengapa sumber stres yang sama dapat mempengaruhi wanita dan laki-laki secara berbeda, hal ini karena depresi secara signifikan yang lebih besar pada wanita 
dibandingkan dengan pria, dan wanita dinyatakan lebih cepat menderita kelelahan, kecemasan (Sirait, 2010)

Karena berdasarkan hasil responden yang telah dijelaskan sebelumnya menunjukan bahwa perawat di RS Krakatau Medika lebih dominan terhadap responen wanita, dan cenderung para perawat tersebut telah menikah dan berkeluarga, sehingga mereka memilki peran ganda yang dijalankan, dan penjelasan pada diesi stres kerja sebelumnya, juga dapat menyebakan stres kerja yang dialami perawat pada dimensi ini menunjukan nilai yang tinggi. Karena perawat di Rumah Sakit Krakatau Medika merasakan bahwa waktu kerja yang dimiliki oleh perawat cukup menyita waktunya bersama keluarga, karena sistem kerja yang dimiliki perawat tersebut cenderung lebih banyak memiliki waktu kerja dengan sistem shift. Dimana ketika pulang ke ruamh perawat harus tetap mengerjakan pekerajaan rumahnya walaupun dengan keadaan sangat lelahm namun seabgai seorang ibu tangga akan selalu ada apalagi jika mempunyai anak kecil. Perawat sering menitipkan anak di tempat peneitipan anak. Perawat merasa kasihan karena nakanya sering di tinggal dan sering merasa cemas jika kondidi anak sakit daring meminta izin kepada kepala perawa untuk melihat anaknya. Oleh sebab itu responden lebih dominan setuju dengan pernyataan bahwa keluarga mereka ingin lebih menghabiskan banyak waktu dengan keluargnya. Dan pengadian yang dirasakan oleh perawat sebagian bertetangan dengan pengabdian kepada keluargnya.

Tabel 2 Statistik Deskriptif Variabel Kepuasan Kerja

\begin{tabular}{|l|r|r|r|r|r|}
\hline & $\mathrm{N}$ & Minimum & Maximum & Mean & $\begin{array}{c}\text { Std. } \\
\text { Deviation }\end{array}$ \\
\hline Pay & 140 & 2.00 & 4.50 & 3.4786 & .55253 \\
Work it selft & 140 & 3.50 & 4.00 & 3.9096 & .07290 \\
Promotion & 140 & 2.00 & 4.50 & 3.4214 & .54730 \\
Supervision & 140 & 2.00 & 4.50 & 3.6036 & .58302 \\
Coworker & 140 & 2.00 & 4.50 & 3.6071 & .57772 \\
Kepuasan Kerja & 140 & 2.68 & 4.19 & 3.6041 & .30480 \\
Valid N (listwise) & 140 & & & & \\
\hline
\end{tabular}

Sumber : Hasil olah SPSS (2016)

Secara keseluruhan, kepuasan kerja perawat di Rumah Sakit Krakatau Medika berada pada tingkat tinggi. Terlihat dari nilai rata-rata sebesar 3,60 yang berada pada interval 3,41-4,20 dan untuk tingkat variansi jawaban dapat dikatakan cukup tinggi, yakni hanya sebesar $8,45 \%$, persentase tersebut diperoleh dari nilai Standar deviasi dimensi ini yaitu sebesar 0,304, hal tersebut menunjukan bahwa dimensi tersebut tidak lebih dari $20 \%$ artinya jawaban-jawaban terhadap pernyataan serupa. Hasil penelitian menunjukan bahwa kepuasan kerja pada dimensi pekerjaan itu sendiri memiliki nilai tertinggi yaitu 3,90 yang berarti bahwa dimensi tersebut dalam katagori tinggi. Sedangkan pada dimensi promosi menunjukan nilai terendah dari dimensi kepuasan kerja lainya, yaitu 3,42.

Dimensi dengan nilai mean terendah ditunjukan oleh dimensi promosi, dan dimensi dengan katagori tertinggi yaitu dimensi pekerjaan itu sendiri. Kedua dimensi tersebut menunjukan katagori baik. Hal yang mengindikasi bahwa dimensi pekerjaan itu sendiri. Karena perawat memiliki jawaban dengan nili tertinggi lima, hal tersebut menunjkan bahwa perawat merasa pekerjaan yang mereka kerjakan menarik walupun dilihat dari beban kerja yang dimilik perawat cukup tinggi. Oleh karena itu beberapa perawat merasa bahwa mereka telah mencapai keberhasilan dalam pekerjaan mereka. Hal tersebut sesuia dengan pernyataan Norman (2005) dalam Nugroho (2012), menjelaskan kepuasan kerja merupakan ukuran seeseorang terhadap kepuasan yang dilihat dari komponen intrinsik dan ekstrinsik dari pkerjaan tersebut. Diakui pula bahwa kepuasan kerja merupakan faktor yang mungkin paling penting yang mempengaruhi keinginan perawat untuk tetap dalam keperawatan. Hal tersebut didukung oleh pernytaan perawatat yang menjelaskan bahwa kepusan sebagai perawat di dukung dengan keamanan kerja yang telah ditentukanoleh perusahaan dan dengan kerapihan serta kebersihan lingkungan kerja yang selalau tejaga. 
Pada dimensi gaji menunjukan bahwa responden lebih dominan merasakan bahwa gaji yang mereka terima telah sesuai dengan tanggung jawab pekerjaan karyawan. Karena berdasarkan peryataan perawat di Rumah Sakit Krakatau Medika bahwa kepuasan karyawan yang dirasakan yang disebabkan oleh gaji yang diterima telah sesuai dengan UMR (Upah Minimum Regional) kota Cilegon, selain pemeberian gaji yang diterima oleh perawat, bahwa perawat di RS Krakatau Medika menerima tunjangan kesehatan. Namun bebepara perawat beranggapan bahwa gaji yang diterima masih belum sesuai dengan tanggung jawab yang diberikan. Berdasarkan hasil wawancara tidak terstruktur terhadap kepala perawat di RS Krakatau Medika, menjelasakan bahwa penyebab kepuasan kerja berdasarkan gaji tidak tinggi, yaitu karena sebenarnya gaji pekerja di bidang layanan kesehatan yang notaben sudah lumayan tinggi dibandingkan karyawan pabrik, akan tetap dipersepsikan sedang oleh para perawat di RS Krakatau Medika, karena mereka beranggapan bahwa gaji yang cukup tinggi dibandingkan pekerja sektor swasta tersebut sudah semestinya mereka terima sesuai dengan beban berat pekerjaan mereka sebagai perawat yang harus bisa selalu sabar menghadapi banyak karakter pasien. selain itu perawat menginginkan tuntutan yang tinggi dari pekerjaan karena jam tambahan lainya diluar jam kerja dan kerja shift itulah yang membuat perawat mudah stres dan merasa kelelahan sehinga ingin mendapatkan gaji yang tinggi.

Menurut penelitian Theriault dalam Suhendi \&Anggara (2010: 195), menjelaskan bahwa kepuasan kerja merupakan fungsi dari jumlah absolut dari gaji yang diterima, sejauh mana gaji memenuhi harapan-harapan tenaga kerja, dan bagaimana gaji diberikan. Dengan meengnukan teori motivasi Admans, gaji yang dipersepsikan sebagai terlalu kecil atau telalu besat akan mengalami distress (ketidakpuasan).

Sedangkan untuk dimensi promosi merupaka dimensi yang memiiki nilai mean tertinggi adalah indikator karena perawat merasa puas dengan kesempatan untuk mengembangkan karir. Dimana jabatan perwat di Rumah Sakit Krakatau Medika terdidri dari beberapa kelompok yaitu ada kepala ruangan, ketua team/PN dan perawat pelaksana. Promosi bagi perawat unutk mengembangkan karirnya dilakukan yaitu degan cara pemenuhan rencana kerja dan target adalah seorang PNS. Sedangkang untuk perwat yang berstatus kontak dapat meningkatkan jawabatanya dengan terpenuhinya sasana kerja pegawai yang telah ditentukan.

Dari dimensi supervision berada pada interval 3,41-4,20 yaitu sebesar 3,60 yang artinya bahwa dimensi ini berada pada tingkat tinggi, oleh karena itu tingkat kepuasanan kerja yang dimiliki perawat bagian rawat inap di Rumah Sakit Krakatau Medika yaitu dalam katagori tinggi. Hal tersebut dikarenakan kepala perawat bersikap adil dengan semua bawahnya, dan kepala perwat selalau mendengarkan keluhan dari para perawat, selain itu kepala perawat selalu memberikan pengaraman, dan hal-hal positif diberikan supervisor kepada perawt di Rumah Sakit Krakatau Medika yaitu dengan diberikanya reward dan punissmen secara fair terhadap karyawan, seperti pada pemeberian tunjungan hari raya, namun berdasarkan pernyataan perawat di Rumah Sakit Krakatau Medika menjelaskan bahwa mereka jarang melakuan getrhing, fasilitas yang diberikan perusahaan selain hal-hal diatas yaitu, fasilitas bus antar jemput karywan, sehingga hal tersebut dapat mengurangi dampak dari stres kerja yang ditimbulkan dari faktor lingkungan.

Untuk dimensi rekan kerja responden lebih menjawab dominan dengan baik bersarkan hasil perolehan nilai rata-rata pada dimensi ini, dimana perawat RS Krakatau Medika merasa bahwa rekan kerja mereka menunjukan sikap bersahabat dan saling mendukung dan tanggung jawab dalam lingkungan kerja, hal tersebut menunjukan bahwa kepuasan yang dimiliki oleh perawat Krakatau Medika termasuk dalam katagoti cukup baik. Namun sebagian perwat masih merasakan bahwa tingkat kepuasan yang di dapatkan selama bekerja di RumahSakit Krakatau Medika masih dirasa kurang, hal tersebut dapat dilihat dari indikasi perawat yang menunjukan tingkat stres yang sedang.

Tabel 4.23 Hasi Uji Korelasi Sederhana

\begin{tabular}{|ll|r|r|}
\hline & & Stres Kerja & Kepuasan Kerja \\
\hline \multirow{2}{*}{ Stres Kerja } & Pearson Correlation & 1 & .352 \\
& Sig. (2-tailed) & & .000
\end{tabular}




\begin{tabular}{|c|c|c|c|}
\hline & $\mathrm{N}$ & 140 & 140 \\
\hline \multirow{3}{*}{ Kepuasan Kerja } & Pearson Correlation & .352 & 1 \\
\hline & Sig. (2-tailed) & .000 & \\
\hline & $\mathrm{N}$ & 140 & 140 \\
\hline
\end{tabular}

**. Correlation is significant at the 0.01 level (2-tailed).

Sumber : Hasil olah SPSS (2016)

Berdasarkan tabel diatas, dapat dilihat bahwa nilai korelasi antara variabel stres kerja dan kepuasan kerja sebanyak 0,351. Jika mengacu pada inerprestasi korelasi menurut Sugiyono (2013:231), maka nilai korelasi tersebut termasuk dalam korelasi yang rendah karena berada pada interval 0,20-0,399. Nilai korelasi Person pada tabel di atas menunjukan nilai positif yang sedang, maka hubungan antara stres kerja dengan kepuasan kerja searah, yang artinya jika stres kerja meningkat maka akan diikuti oleh peningkatan kepuasan kerja perawat di Rumah Sakit Krakatau Medika.

\section{Uji Hipotesis}

Untuk mengetahui stres kerja berpengaruh signifikan terhadap kepuasan kerja, aka uji hipoteis dengan rumusan hipotesis sebagai berikut:

$\mathrm{H}_{0}$ : Stres kerja tidak berpengaruh secara signifikan terhadap kepuasan kerja.

Ha: Stres kerja berpengaruh positif dan signifikan terhadap kepuasan kerja.

Dalam penelitian ini, uji hipotesis yang digunkan adalah uji satistik T.

1. Uji statistik T

Uji statistik T digunakan untuk mengetahui apakah stres kerja berpengaruh signifikan terhadap kepuasan kerja

Tabel 4.26 Uji Statistik T

\begin{tabular}{|c|c|c|c|c|c|}
\hline \multirow[t]{2}{*}{ Model } & \multicolumn{2}{|c|}{ Unstandardized Coefficients } & \multirow{2}{*}{$\begin{array}{c}\begin{array}{c}\text { Standardized } \\
\text { Coefficients }\end{array} \\
\text { Beta }\end{array}$} & \multirow[t]{2}{*}{$\mathrm{t}$} & \multirow[t]{2}{*}{ Sig. } \\
\hline & B & Std. Error & & & \\
\hline (Constant) & 25.676 & 2.344 & & 10.953 & .000 \\
\hline Stres Kerja & .160 & .036 & .352 & 4.414 & .000 \\
\hline
\end{tabular}

a. Dependent Variable: Kepuasan Kerja

Sumber : Hasil olah SPSS (2016)

Dari tabel diatas, terlihat bahwa nilai signifikansi untuk stres kerja adalah sebesar $0,000<\alpha$ $=0,05$ dan niali $\mathrm{t}$ hitung untuk kepuasan kerja adalah sebesar 4,414. Nilai $\mathrm{t}$ hitung ini akan dibandingkan dengan nilai t tabel pada tabel distribusi $\alpha=5 \% ; 2=2,5 \%$ (uji 2 sisi) dengan nilai kebebasan (df) (n jumlah data), df sebesar n-k=138, dengan pengujian dua sisi hasil perloleh untuk $\mathrm{t}$ tabel sebesar 1,977 jadi nilai t hitung lebih besar dibanding dengan t tabel. Hal tersebut menunjukan bahwa Ho ditolak, artinya stres kerja berpengaruh positif dan signifikan terhadap kepuasan kerja.

\section{Uji F}

Uji $F$ juga dilakukan untuk menguji apakah model regresi signifikan atau tidak. Uji $F$ dilakukan dengan cara membandingkan $\mathrm{F}$ hitung dengan $\mathrm{F}$ tabel. Jika $\mathrm{F}$ hitung lebih besar dari pada $\mathrm{F}$ tabel, maka Ho ditolak dan Ha diterima. Namun, jika F hitung lebih kecil dari pada F tabel, maka Ho diterima dan Ha ditolak. 
Berdasarkan tabel 4.27 dapat diketahui bahwa nilai $\mathrm{F}$ hitung untuk stres kerja terhdap kepuasan kerja adalah sebesar 16,823. Untuk nilai $F$ tabel dengan signifikan 0,05 harus memperhatikan hal berikut:

$\mathrm{df} 1=\mathrm{k}-1=1$

$\mathrm{df} 2=\mathrm{n}-\mathrm{k}=138$

Dari hasil perhitungan F tabel yang diperoleh dengan signifikansi 0,05 , df1 $=1$ dan df $2=138$ adalah sebesar 1,977. Dengan demikian nilai $\mathrm{F}$ hitung lebih besar dari pada nilai $\mathrm{F}$ tabel sehingga dapat disimpulkan bahwa Ho ditolak dan Ha diterima.Dengan kata lain, kriteria pengujian hipotesisi Ho ditoalak, artinya stres kerja berpengaruh positif dan signifikan terhadap kepuasan kerja Hasil uji F dapat dilihat pada tabel 4.27.

Tabel 4.27 Uji F

\begin{tabular}{|ll|r|r|r|r|r|}
\hline Model & & Sum of Squares & df & Mean Square & F & \multicolumn{1}{|c|}{ Sig. } \\
\hline & Regression & 162.790 & 1 & 162.790 & 16.823 & $.000^{\mathrm{b}}$ \\
1 & Residual & 1335.381 & 138 & 9.677 & & \\
& Total & 1498.171 & 139 & & & \\
\end{tabular}

a. Dependent Variable: Kepuasan Kerja

b. Predictors: (Constant), Stres Kerja

Sumber : Hasil olah SPSS (2016)

\section{Uji Regresi Linear Sederhana}

Analisis regresi linear sederhana digunkan pula untuk memeprediksi bagaimana perubahan nilai stres kerja jika nilai keouasan kerja perawat rawat inap di Rumah Sakit Krakatau Medika Cilegon, dinaikan atau diturunkan. Untuk lebih jelasnya dapat dilihat pada gambar

\section{Tabel 4.24 Hasi Uji Regresi Linear Sederhana}

Coefficients $^{\mathrm{a}}$

\begin{tabular}{|c|c|c|c|c|c|}
\hline \multirow[t]{2}{*}{ Model } & \multicolumn{2}{|c|}{$\begin{array}{l}\text { Unstandardized } \\
\text { Coefficients }\end{array}$} & \multirow{2}{*}{$\begin{array}{c}\begin{array}{c}\text { Standardized } \\
\text { Coefficients }\end{array} \\
\text { Beta }\end{array}$} & \multirow[t]{2}{*}{$\mathrm{t}$} & \multirow[t]{2}{*}{ Sig. } \\
\hline & B & Std. Error & & & \\
\hline (Constant) & 25.676 & 2.344 & & 10.953 & .000 \\
\hline Stres Kerja & .160 & .036 & .352 & 4.414 & .000 \\
\hline
\end{tabular}

a. Dependent Variable: Kepuasan Kerja

Sumber : Hasil olah SPSS (2016)

Berdasarkan tabel diatas, dapat dilihat bahwa konstanta sebesar 25,676 (a) dengan koefesien regresi linear sebesar 0,160 (b). dari hasil tersebut diperoleh model regresi linear sederhana sebagai berikut.

$$
\begin{aligned}
& Y=a+B x \\
& Y=25,676+0,160 X
\end{aligned}
$$

Nilai a dan b di atas dapat diintrepertasikan sebagai berikut : 
1. Konstanta sebesar 25,676 dapat diartikan jika stres kerja sama dengan kepuasan kerja nol $(X=0)$ atau tidak ada kepuasan kerja, maka stres kerja hanya sebesar 25,676.

2. Kepuasan kerja memiliki nilai koefesien regresi linear sebesar 0,160 . Hal ini mengandung arti bahwa apabila stres kerja mengalami keniakan satu satuan maka kepuasan kerja akan mengalami keanikan sebesar 0,160 .

\section{Uji $\mathbf{r}^{2}$ (Koefesien Determiasi)}

Koefesien determinasi digunakan untuk melihat kontribusi pengaruh yang diberikan variabel bebas (Stres Kerja) terhadap variabel terikat (Kepuasan kerja). Dengan menggunkan bantuan sofware SPPS 20 diperoleh hasil koefesien determinasi sebagai berikut.

\section{Tabel 4.25 Koefesian Determinasi}

\section{Model Summary}

\begin{tabular}{|l|r|r|r|r|}
\hline Model & \multicolumn{1}{|c|}{$\mathrm{R}$} & R Square & \multicolumn{1}{c|}{$\begin{array}{c}\text { Adjusted R } \\
\text { Square }\end{array}$} & $\begin{array}{c}\text { Std. Error of } \\
\text { the Estimate }\end{array}$ \\
\hline 1 & $.352^{\mathrm{a}}$ & .124 & .117 & 3.420 \\
\hline
\end{tabular}

a. Predictors: (Constant), Stres Kerja

b. Dependent Variable: Kepuasan Kerja

Sumber : Hasil olah SPSS (2016)

Dari tabel diatas dapat diketahui bahwa korelasi antara variabel stres kerja dengan kepuasan kerja dapat dilihat pada $\mathrm{R}$ yang menunjukan nilai 0,352. Menurut sugiyono (2013) nilai korelasi antara 0,20-0,399 memiliki hubungan rendah. Maka $\mathrm{R}$ 0,352 mempunyai arti bahwa hubungan yang rendah antara stres kerja dengan kepuasan kerja.

Besarnya peangaruh stres kerja terhdap kepuasan kerja, dapat dilihat pada angka $\mathrm{R}$ squere (angka korelasi yang dikuadratkan). Besarnya angka $\mathrm{R}$ squere sama dengan 0,124 . $\mathrm{R}$ squere tersebut mengandung arti bahwa secara statstitik bahwa sebesar $12,4 \%$ variabel stres kerja dapat dijelaskan oleh kepuasan kerja , sedangkan sisanya $100 \%-12,4 \%=87,6 \%$ dijelaskan oleh faktor-faktor lainya yang tidak dibahas dalam penelitian ini.

\section{Kesimpulan dan Saran Kesimpulan}

Berdasarkan hasil pengumpulan data, pengolahan data dan analis yang telah dilakukan, maka dapat menarik kesimpulan. Kesimpulan ini sekaligus menjawab dari perumusan masalah penelitian yaitu:

1. Tingkat stres kerja yang dirasakan oleh perawat bagian rawat inap Rumah Sakit Krakatau Medika Cilegon secara umum berada pada tingkat sedang. Hal ini ditinjau dari enam dimensi yang menunjukan adanya ambiguitas peran (role ambiguity), konflik peran (role conflict), peran berlebih (role overload), tuntutan antarpribadi (inter-personal demands), stuktur organisasi (organizational structure), dan situsi rumah dan pekerjaan. Hasil penelitian menujukan bahwa stres kerja pada dimensi situasi rumah dan pekerjaan, dengan nilai tertinggi yaitu 3,85 yang termasuk pada katagori sedang. Namun pada dimensi struktur organisasi memiliki nilai terendah yaitu 2,47 yang menunjukan katagori rendah.

2. Tingkat Kepuasan kerja perawat bagian rawat inap Rumah Sakit Krakatau Medika Cilegon berada pada tingkat yang tinggi. Hal ini dilihat dari Upah (Pay), Pekerjaan itu Sendiri, Promosi (promotion), Pengawasan atasan (supervision), Rekan kerja (coworker). Hasil penelitian menunjukan bahwa kepuasan kerja pada dimensi pekerjaan itu sendiri memiliki nilai tertinggi yaitu 3,90 yang berarti bahwa dimensi tersebut dalam katagori tinggi. Sedangkan pada dimensi promosi menunjukan nilai terendah dari dimensi kepuasan kerja lainya, yaitu 3,42.

3. Terdapat pengaruh stres kerja terhadap kepuasan kerja perawat bagian rawat inap Rumah Sakit Krakatau Medika Cilegon. pengaruh stres kerja terhdap kepusan kerja berdasarkan hasil uji regresi 
yang memiliki pengaruh sebesar 12,4\%. dan sisanya 87,6\% digambarkan atau dijelaskan oleh faktor-faktor lain itu, yaitu balas jasa, penempatan karyawan, lingkungan kerja, gaya kepemimpinan.

\section{Saran}

Dari hasil kesimpulan di atas menunjukan bahwa terdapat beberapa saran yang dapat diberikan, yaitu:

1. Untuk mengelolah sumber stres yang berasal dari organisasi. Maka yang perlu dilakukan organisasi yaitu:

a. Menyediakan pelatihan manajemen stres dan program pendapingan karyawan (Employee Assistance Program/EAP) untuk meningkatkan kemampuan karyawan dalam mengatasi situasi kerja yang sulit. Dalam program manajemen stres diajarkan pada karyawan sumber stres yang berasal dari organisasi dan keterampilan individu untuk mengurangi stres, manajemen waktu dan relaksai.

b. Menggunakan pendektatan dukungan sosial yang diberikan peruhasan, dengan melakukan aktivitas-aktivitas yang diadakan perusahaan dengan tujuan memberikan kepuasan sosial karyawan, seperti bermain game, dan sering diadakannya gethring. Selain itu perusahan dapat melakukan pendekatan biofeedback yaitu pendekatan yang dilakukan melalui bimbingan medis, seperti bimbingan dokter, psikiater, dan psikolog.

2. Sebaiknya perusahaan perlu memperhatikan kepuasan kerja dalam hal promosi dan gaji, sebaiknya perlu diberitahukan syarat dan ketentuan yang jelas untuk perawat agar dapat megikuti promosi khusnya untuk perawat yang masih kontrak agar dapat menjadi perawat tetap. Dalam pemeberian sistem kompensasi sebaiknya harus dievaluasi dahulu apakkah pemeberian gaji, bonus, dan tunjagan sudah sesuai atau belum jika diterapkan saat ini. Selain itu diharapkan perawat di RS Krakatau Medika Cilegon dapat membangun komunikasi lebih baik agar perawat dapat mengeluarkan aspirasinya untuk kemajuan Rumah Sakit.

3. Dalam penelitian ini, penulis hanya memeliti faktor stres kerja yang berhubungan dengan kepuasan kerja karyawan. Sehingga pada hasil penelitian ini menunujakan bahwa pengaruh stres kerja terhadap kepuasan kerja perawat di RS Krakatau Medika memiliki pengaruh yang kecil. Oleh karena itu diharapkan bagi peneliti selanjutnya, untuk menambah atau memilih variabel lain yang dapat meningkatkan kepuasan kerja karyawan, karena masih banyak secara teoritis, yang dapat mempengaruhi kepuasan kerja karyawan, faktor lain yang dapat diteliti selain stres kerja yaitu faktor psikologis, faktor sosial, penempatan karyawan, lingkungan kerja, gaya kepemimpinan, mutu pengawasan.

\section{Daftar Pustaka}

Afandi, Pandi. (2016). Concept \& Indicator Human Resources Management for Management Reseach. Yogyakarta: Deepublish.

Arikunto, S. (2010). Prosedur Penelitian: Suatu Pendekatan Praktik. Jakarta: Rineka Cipta.

I Gede, Putro Wibowo. (2014). Pengaruh Stres Kerja Terhadap Kepuasan Kerja dan Komitmen Organisasional Karyawan UD.Ulam Sari Denpasar. Tesis. Universitas Udayana Denpasar.

Kreitner, R., \& Kinicki, A. (2014). Organization Behaviour $5^{\text {th }}$ edition. Boston: McGraw-Hill Education.

Leung, Mei-yung and Janet, Sham and Yee, shan Chan. (2007). Adjusting Stressors -JobDemand Stress in Preventing Rustout/Burnout in Estimators. Surveying and Built Environment. Vol .18 (1), pg. 17-26 ISSN 1816-9554.

Luthans, Fred. (2006). Perlaku organisasi. Edisi 10. Yogyakarta: Andi.

Mangkunegara, A,A Anwar, P. (2013). Manajemen Sumber Daya Manusia Perusahaan. Bandung: PT Remaja Rosdakarya. 
Mansoor Muhamaad, Sabtain Fida, Saima Nasir, Zubair, (2011). The Impact of Job Stress on Employee job Satisfaction A Study on Telecommunication Sector of Pakistan Journal of Business Studies Quaterly, Vol 2, No. 3, pp 50-56.

Moorhead, G., \& Griffin, R. W. (2013). Perilaku Organisasi: Manajemen Sumber Daya Manusia dan Organisasi. Edisi 9. (Diterjemahkan oleh: D. Angelica). Jakarta: Salemba Empat.Potter, P.A., \& Perry, a.g.(2005). Fundamentals of nursing: concepts, process, and practice. Mosby-Year Bookk Inc.

Ratna, D. (2010). Pengaruh Stres kerja Terhadap Kinerja Pegawai Negeri Pusat Direktorat Jendral Kekayaan Negara. Jakarta: Universitas Mercu Buana.

Rivai, Zainal, Veithzal, Muliaman, D.H \& Mansyur R. (2014). Kepemimpinan dan Prilaku Organisasi. Jakarta: PT.Raja Grafindo Persada.

Robbins,Stephen P \&.Timothy A . (2013). Organizational behavior. New Jersey: Pearson Education, Inc.

Robbins, Stephen P \&.Timothy A .(2014). Perilaku Organisasi edisi sebelas (Tim Indeks,Penerjemah.). Jakarta : PT Indeks Kelompok Gramedia.

Sugiyono. (2013). Metode Penelitian Kuantitatif Kualitatif dan $R \&$ D. Bandung: Alfabeta.

Suhendi, Hendi, \& Anggara . (2010). Prilaku Organisasi. Bandung: CV Pustka Setia.

Tsai, Ming-Tien and Huang, Chun-Chen. (2008). The Relationship among Ethical Climate Types, Facets of Job Satisfaction, and the Three Components of Organizational Commitment: A Study of Nurses in Taiwan. Journal of Business Ethics. Vol. 3, No. 8, pp 65-581.

Umar, Husein. (2011). Evaluasi Kinerja Karyawan. Jakarta: PT Gramedia Pustaka Utama. Media Grup.

Undang-Undang Keperawatan Nomor 38 Tahun 2014 Tentang Kesehatan. http://www.hukor.depkes.go.id. Diakses: 6 Mei 2016.

Wahjono, Sentot Imam. (2010). Prialku Oragnisasi. Yogyakarta: Graha Ilmu. 